\title{
Theoretical Investigation of the Hydrogenated Aluminum Cobalt Clusters
}

\author{
Ling Guo
}

School of Chemistry and Material Science, Shanxi Normal University, Linfen 041004, China

Correspondence should be addressed to: Ling Guo; gl-guoling@163.com

Received date: 29 May 2014; Accepted date: 7 July 2014; Published date: 19 September 2014

Academic Editor: Juguang Han

Copyright (C) 2014. Ling Guo. Distributed under Creative Commons CC-BY 3.0

\begin{abstract}
The chemisorptions of hydrogen on aluminum cobalt clusters are studied with density functional theory. The on-top site is identified to be the most favorable chemisorptions site for hydrogen, and the Al-top sites are the preferred one in the most cases for one hydrogen adsorption in $\mathrm{Al}_{n} \mathrm{Co}$ except for $\mathrm{Al}_{n} \mathrm{Co}(\mathrm{n}=1,4,6$, and 11) clusters. Top on the neighboring or opposition $\mathrm{Al}$ and $\mathrm{Al}$ atoms ground-state structures are found for two hydrogen adsorption on $\mathrm{Al}_{\mathrm{n}} \mathrm{Co}$. The $\mathrm{Al}-\mathrm{Co}, \mathrm{Al}-\mathrm{H}$ and $\mathrm{Co}-\mathrm{H}$ bond lengths evolve very slowly with cluster size; and there is a slight increase in the mean $\mathrm{Al}-\mathrm{Co}$ bond lengths after $\mathrm{H}$ adsorption on the AlCo clusters. In addition, the nearly constant value for $\mathrm{Co}-\mathrm{H}$ and $\mathrm{Al}-\mathrm{H}$ bond lengths on different clusters suggests their similar nature of bonding of $\mathrm{H}$. In general, the binding energy of $\mathrm{H}$ and $2 \mathrm{H}$ are both found to decrease with a decrease in the cluster size. The large binding energies of the hydrogen and the large HOMO-LUMO gaps for $\mathrm{Al}_{3} \mathrm{CoH}, \mathrm{Al}_{15} \mathrm{CoH}$ and $\mathrm{Al}_{14} \mathrm{CoH}_{2}$ make these species behaving like magic clusters. Their stability is further suggesting by the fragmentation energies.
\end{abstract}

Keywords: Hydrogenated aluminum cobalt cluster; electronic properties; Density functional theory

\section{Introduction}

Bulk phase bimetallic systems provide a matter of increasing interest in pure and applied materials sciences and traditional fields of physics and chemistry (Lee et al. 2003; Singh et al. 2005; David and Sylvia 2006; Passacantando et al. 2006; Chen and Johnson 2008; Quyuan et al. 2008). In catalytic chemistry and chemical engineering, real catalysts mainly consist of a heterometallic or bimetallic system, which can profoundly enhance reactivity and selectivity (Bond 1987). Thus, to get a deeper understanding of the microscopic behavior of these species, the study of bimetallic or so-called alloy clusters provides a suitable tool, since cluster science enables one to

Cite this Article as: Ling Guo (2014), "Theoretical Investigation of the Hydrogenated Aluminum Cobalt Clusters", Journal of Research in Nanotechnology, Vol. 2014 (2014), Article ID 850303, DOI: $10.5171 / 2014.850303$ 
investigate chemical and physical properties starting from a single atom or molecule toward bulk phase as a function of size. Therefore, in the last decades a number of studies of bimetallic clusters and diatomic molecules have been performed (Tian et al. 2008; Laguna et al. 2010; Zanti and Peeters 2010; Lu et al. 2011; Zhao et al. 2011).

Among the candidate systems to have been considered, the bimetallic aluminum cobalt clusters

That has been the topic of some experimental and theoretical studies (Koel et al. 1985; Nonose et al. 1989; Menezes et al. 1991, 1993; Behm et al. 1994). Several years ago, Nonose and co-workers (1989) performed chemisorptions reactivity studies of neutral $\mathrm{Al}_{n} \mathrm{Co}_{\mathrm{m}}(\mathrm{n}>\mathrm{m})$ and $\mathrm{Co}_{\mathrm{n}} \mathrm{Al}_{\mathrm{m}}(\mathrm{n}>\mathrm{m})$ clusters toward $\mathrm{H}_{2}$ using a fast flow reactors. In that study, they found that the doping of $\mathrm{Co}_{n}$ clusters with only one $\mathrm{Al}$ atom reveals a remarkable increase of hydrogen chemisorptions rates compared to pure $\mathrm{Co}_{\mathrm{n}}$ clusters. On the other hand, pure $\mathrm{Al}_{\mathrm{n}}$ clusters do not adsorb hydrogen, which is comparable to Al bulk phase behavior (Koel et al. 1985). Knickelbein and coworkers (1991, 1993) succeeded in a comprehensive investigation of the size dependence of ionization energies of these clusters. These ionization energies studies show that the electronic shell structure of $\mathrm{Al}_{n} \mathrm{Co}$ and $\mathrm{Al}_{n} \mathrm{Co}_{2}$ clusters remains similar to that of pure $\mathrm{Al}_{\mathrm{n}}$ clusters. Morse and co-workers (1994) have performed resonant two-photon ionization spectroscopy on small diatomic AlCo aluminides. Pramann and co-workers (2001) have measured the photoelectron spectra of small mass-selected aluminum-rich $\quad \mathrm{Al}_{\mathrm{n}} \mathrm{Co}^{-} \quad(\mathrm{n}=8-17), \quad$ and cobalt-rich $\mathrm{Co}_{\mathrm{n}} \mathrm{Al}_{\mathrm{m}}{ }^{-}$clusters $(\mathrm{n}=6,8,10 ; \mathrm{m}=1$, 2) are measured at photon energies of 3.49 $\mathrm{eV}$ with the aid of a magnetic bottle photoelectron spectrometer.

Since the pioneering work of Knight et al. (1984) exhibiting a direct relationship between the pronounced peaks in the mass ion intensities (commonly referred to as magic numbers) of $\mathrm{Na}$ clusters and electronic shell closure, considerable theoretical and experimental work has been carried out to search for new magic numbers in compounds as well as charged metal clusters (1997). The electronic shell closure derived from the Jellium model dictates that metal clusters with $2,8,20,40$... electrons are particularly stable as they correspond to complete filling of $1 \mathrm{~s}$, $1 \mathrm{~s} 1 \mathrm{p}, 1 \mathrm{~s} 1 \mathrm{p} 1 \mathrm{~d} 2 \mathrm{~s}, 1 \mathrm{~s} 1 \mathrm{p} 1 \mathrm{~d} 2 \mathrm{~s} 1 \mathrm{f} 2 \mathrm{p}$... groups of orbital, respectively. As $\mathrm{Al}, \mathrm{Co}$, and alkali metal atoms exhibit free-electron-like behavior in their respective bulk phases, one would expect the atomic and electronic structure as well as relative stabilities of cobalt-doped aluminum clusters to exhibit the same behavior as those of alkali atom-doped aluminum clusters (1994). Since both clusters contain the same number of valence electron; for example, if clusters are born neutral, $\mathrm{Al}_{13} \mathrm{Co}$ cluster should exhibit enhanced stability (and, hence, a peak in the mass spectra) over their neighbors, as it would contain 40 valence electrons.

Against this background, the sequential growth of small $\mathrm{Al}_{\mathrm{n}}$ Co clusters with $\mathrm{n}=1-17$ (Guo 2007, 2008) have been explored recently. And to obtain further insights on the nature of chemisorption of a single $\mathrm{H}_{2}$ molecule on $\mathrm{Al}_{n} \mathrm{Co}$ clusters, the extensive calculations of chemisorption of $\mathrm{H}_{2}$ and sequential hydrogen loading on the above energetically stable clusters are studied. A detailed picture of chemisorption of $\mathrm{H}_{2}$ on $\mathrm{Al}_{\mathrm{n}} \mathrm{Co}(\mathrm{n}=1-15)$ nanoclusters based on an analysis of energies, HOMO-LUMO gap, Stability, fragmentation behavior, and Bonding nature are presented. So, the understanding of the adsorption of $\mathrm{H}_{2}$ molecule on aluminum cobalt clusters could give useful insight on hydrogen interaction with other alloy clusters.

The paper is organized as follows: A brief account of the computational methodology is given in Sec. 2, followed by a detailed presentation and discussion of the first-principles calculations in Sec. 3 on small aluminum cobalt clusters with $\mathrm{n}=1-15 \mathrm{Al}_{\mathrm{n}} \mathrm{Co}$ and up to two hydrogen atoms. These will provide an understanding of the nature of interaction of hydrogen with aluminum cobalt clusters and the magic behavior of these clusters. A summary of my findings and conclusions are given in Sec. 4. 


\section{Methodology}

All calculations are performed using the density functional theory (DFT) provided by the Gaussian 03 suite of programs (Frisch 2004). The density functional is treated with the generalized gradient approximation (GGA) corrected-exchange potential of the B3LYP (Becke 1993), and its application has been shown to be effective (Guo 2007, 2008). The double- $\xi$ basis set lanl2dz is employed (Hay 1985). Frequency analyses at the optimized structures are carried out at the same theoretical level to clarify if the optimized structures are true minima or transition states on the potential energy surfaces of specific clusters. All of the obtained, most stable clusters are characterized as energy minima without imaginary frequencies. The geometries are fully optimized. The structures of small $\mathrm{Al}_{n} \mathrm{Co}(\mathrm{n}=1-15)$ clusters are reported in my previous paper (Guo 2007, 2008).

Low energy structures may be missed if the starting configurations of the search are not set appropriately. In order to avoid this, ab initio simulations starting with several initial two-dimensional and three-dimensional structures are performed for each $\mathrm{Al}_{n} \mathrm{Co}$ adsorbate cluster. For simulating the adsorption process, different orientations of the molecules with respect to the $\mathrm{Al}_{n} \mathrm{Co}$ cluster are considered for optimization, and the $\mathrm{H}_{2}$ molecules and the $\mathrm{Al}_{n} \mathrm{Co}$ cluster are allowed to relax freely. To avoid computational bias, the cluster and $\mathrm{H}_{2}$ chemisorptions geometries are fully optimized without imposing symmetry constraints until the maximum force is less than $4.5 \times 10^{-4} \mathrm{eV} / \AA$ and the maximum displacement is less than $1.8 \times 10^{-3} \AA$.

The Binding energies (BE) of $\mathrm{Al}_{n} \mathrm{Co}$ and $\mathrm{Al}_{\mathrm{n}} \mathrm{CoH}_{\mathrm{m}}$ are calculated based on eqs (1) and (2).

BE

$$
\left(\mathrm{Al}_{\mathrm{n}} \mathrm{Co}\right)=\mathrm{E}\left(\mathrm{Al}_{\mathrm{n}} \mathrm{Co}\right)-\mathrm{nE}(\mathrm{Al})-\mathrm{E}(\mathrm{Co})
$$

$\mathrm{BE}$

$\left(\mathrm{Al}_{\mathrm{n}} \mathrm{CoH}_{\mathrm{m}}\right)=\mathrm{E}\left(\mathrm{Al}_{\mathrm{n}} \mathrm{CoH}_{\mathrm{m}}\right)-\mathrm{nE}(\mathrm{Al})-\mathrm{E}(\mathrm{Co})-\mathrm{mE}(\mathrm{H})$ (2)

where $m$ and $n$ represent the size of the clusters, $\mathrm{E}\left(\mathrm{Al}_{\mathrm{n}} \mathrm{Co}\right), \mathrm{E}\left(\mathrm{Al}_{\mathrm{n}} \mathrm{CoH}_{\mathrm{m}}\right), \mathrm{E}(\mathrm{Al}), \mathrm{E}(\mathrm{Co})$, and $\mathrm{E}(\mathrm{H})$ are energies of $\mathrm{Al}_{n} \mathrm{Co}, \mathrm{Al}_{n} \mathrm{CoH}_{\mathrm{m}}$ clusters, and $\mathrm{Al}, \mathrm{Co}, \mathrm{H}$ atoms, respectively.

\section{Results and discussions}

\section{Hydrogen on $\mathrm{Al}_{\mathrm{n}} \mathrm{Co}(\mathrm{n}=1-15)$}

The optimized geometries for the adsorption of one and two $\mathrm{H}$ atoms on small $\mathrm{Al}_{\mathrm{n}} \mathrm{Co}(\mathrm{n}=1-15)$ clusters are shown in Fig.1. In Table 1 and 2, the values of the binding energy, the HOMO-LUMO energy gaps, and the mean nearest-neighbor bond lengths of $\mathrm{Al}_{\mathrm{n}} \mathrm{Co}(\mathrm{n}=1-15)$ and $\mathrm{Al}_{\mathrm{n}} \mathrm{CoH}_{m}(n=1-15 ; m=1,2)$ clusters are displayed for all the isomers shown in Fig.1. For the chemisorptions of $\mathrm{H}_{2}$ on the $\mathrm{Al}_{\mathrm{n}} \mathrm{Co}$ cluster, there are three possible adsorption sites: 1-fold on top, 2-fold edge, and 3-fold hollow site. The calculation result shows that the on-top adsorption configuration is energetically most stable. 
Table 1: Binding energies (BE), and HOMO-LUMO gaps of various $\mathrm{Al}_{\mathbf{n}} \mathrm{Co}$ clusters obtained using the B3LYP-DFT method. $\boldsymbol{d}_{\mathrm{Al}-\mathrm{Co}}$ is the mean nearest-neighbor bond lengths between $\mathrm{Al}$ and Co atoms

\begin{tabular}{|l|l|l|l|l|}
\hline & Cluster & Gap $(\mathrm{eV})$ & $\mathrm{BE}$ & $d_{\mathrm{Al-Co}}(\AA)$ \\
\hline $1 \mathrm{a}$ & $\mathrm{AlCo}$ & 2.53 & 1.85 & 2.503 \\
\hline $2 \mathrm{a}$ & $\mathrm{Al}_{2} \mathrm{Co}$ & 1.70 & 3.52 & 2.514 \\
\hline $3 \mathrm{a}$ & $\mathrm{Al}_{3} \mathrm{Co}$ & 2.34 & 4.88 & 2.253 \\
\hline $4 \mathrm{a}$ & $\mathrm{Al}_{4} \mathrm{Co}$ & 1.13 & 7.24 & 2.575 \\
\hline $5 \mathrm{a}$ & $\mathrm{Al}_{5}$ Co & 1.34 & 8.70 & 2.282 \\
\hline $6 \mathrm{a}$ & $\mathrm{Al}_{6}$ Co & 1.30 & 11.03 & 2.533 \\
\hline $7 \mathrm{a}$ & $\mathrm{Al}_{7} \mathrm{Co}$ & 1.98 & 13.04 & 2.494 \\
\hline $8 \mathrm{a}$ & $\mathrm{Al}_{8} \mathrm{Co}$ & 1.93 & 15.11 & 2.427 \\
\hline $9 \mathrm{a}$ & $\mathrm{Al}_{9} \mathrm{Co}$ & 1.78 & 16.87 & 2.557 \\
\hline $10 \mathrm{a}$ & $\mathrm{Al}_{10} \mathrm{Co}$ & 1.25 & 18.39 & 2.567 \\
\hline $11 \mathrm{a}$ & $\mathrm{Al}_{11} \mathrm{Co}$ & 1.67 & 20.86 & 2.513 \\
\hline $12 \mathrm{a}$ & $\mathrm{Al}_{12} \mathrm{Co}$ & 1.62 & 22.70 & 2.471 \\
\hline $13 \mathrm{a}$ & $\mathrm{Al}_{13} \mathrm{Co}$ & 2.33 & 25.47 & 2.555 \\
\hline $14 \mathrm{a}$ & $\mathrm{Al}_{14} \mathrm{Co}$ & 1.58 & 27.66 & 2.546 \\
\hline $15 \mathrm{a}$ & $\mathrm{Al}_{15} \mathrm{Co}$ & 1.84 & 29.48 & 2.506 \\
\hline
\end{tabular}

The predicted ground-state spin multiplicity for AlCo is found to be a triplet. The calculated equilibrium bond length is $2.50 \AA$. The associated Al-Co stretching frequency for the ground-state cluster is $267 \mathrm{~cm}^{-1}$. It is seen that the $\mathrm{BE}$ of $\mathrm{H}$ on $\mathrm{AlCoH}(2.23 \mathrm{eV})$ is different to that of $\mathrm{H}$ on AlCo (5.58 eV). This shows that both $\mathrm{AlCoH}$ and $\mathrm{AlCoH}_{2}$ have different stability.

The ground-state $\mathrm{Al}_{2} \mathrm{Co}$ cluster is a spin doublet isosceles triangle with $\mathrm{C}_{2 \mathrm{v}}$ symmetry and a binding energy of $3.52 \mathrm{eV}$. The ground state corresponding to $\mathrm{Al}_{2} \mathrm{CoH}$ cluster is a spin triplet with a Al-H bond length of $1.64 \AA$
(Table 2) and an Al-H stretching frequency of $1751 \mathrm{~cm}^{-1}$, and the $\mathrm{H}$ atom takes on-top adsorption with the $\mathrm{Al}$ atom, which is different from the structure of $\mathrm{AlCoH}$ with 2-fold edge model. The $\mathrm{BE}$ of $\mathrm{H}$ on $\mathrm{Al}_{2} \mathrm{Co}$ is $6.22 \mathrm{eV}$. The $\mathrm{C}_{2 \mathrm{v}}$ isomer [Fig. 1(2c)] with two $\mathrm{H}$ atoms bridging in two $\mathrm{Al}$ atoms is found for the most stable geometry of $\mathrm{Al}_{2} \mathrm{CoH}_{2}$ cluster. Other optimized geometries are also considered for this cluster, for example, occupied different places of $\mathrm{Al}$ and $\mathrm{Co}$ atom (2d) or two $\mathrm{H}$ atoms are located on top $\mathrm{Al}$ atoms $(2 \mathrm{e})$. None of them are more stable than the ground state structure.

Table 2: Binding energies (BE's), structures, and HOMO-LUMO gaps of various clusters obtained using the B3LYP-DFT method. $d_{\mathrm{Al}-\mathrm{Co}}, d_{\mathrm{Al}-\mathrm{H}}$, and $d_{\mathrm{Co}-\mathrm{H}}$, are the mean nearest-neighbor bond lengths between $\mathrm{Al}$ and Co atoms, $\mathrm{Al}$ and $\mathrm{H}$ atoms, Co and $\mathrm{H}$ atoms. Location of $\mathrm{H}$ is represented by symbols $n, o, b, f, t, h$ which mean neighboring, opposite, bridge, farthest, top and hollow site, respectively

\begin{tabular}{|l|l|l|l|l|l|l|l|l|}
\hline & Cluster & $\begin{array}{l}\text { Location } \\
\text { Of } \mathrm{H}\end{array}$ & $\begin{array}{l}\text { Gap } \\
(\mathrm{eV})\end{array}$ & $\begin{array}{l}\text { Total BE } \\
(\mathrm{eV})\end{array}$ & BE of H (eV) & $\begin{array}{l}d_{\mathrm{Al-Co}} \\
(\AA)\end{array}$ & $\begin{array}{l}d_{\mathrm{ArH}} \\
(\AA)\end{array}$ & $\begin{array}{l}D_{\mathrm{Co}-\mathrm{H}} \\
(\AA)\end{array}$ \\
\hline $1 \mathrm{~b}$ & $\mathrm{AlCoH}$ & $\mathrm{b}(\mathrm{Al}, \mathrm{Co})$ & 2.28 & 4.08 & 2.23 & 2.470 & 2.011 & 1.622 \\
\hline $1 \mathrm{c}$ & $\mathrm{AlCoH}_{2}$ & $\mathrm{t}(\mathrm{Al}, \mathrm{Al})$ & 3.61 & 7.43 & 5.58 & 2.417 & 1.619 & \\
\hline 2b & $\mathrm{Al}_{2} \mathrm{CoH}$ & $\mathrm{t}(\mathrm{Al})$ & 2.12 & 6.22 & 2.97 & 2.553 & 1.635 & \\
\hline 2c & $\mathrm{Al}_{2} \mathrm{CoH}_{2}$ & $\mathrm{~b}(\mathrm{Al}, \mathrm{Al})$ & 3.23 & 8.94 & 5.42 & 2.584 & 1.828 & \\
\hline
\end{tabular}




\begin{tabular}{|c|c|c|c|c|c|c|c|c|}
\hline $2 d$ & $\mathrm{Al}_{2} \mathrm{CoH}_{2}$ & $\begin{array}{l}\mathrm{t}, \mathrm{b}(\mathrm{Al}, \\
\mathrm{Co})\end{array}$ & 3.10 & 8.77 & 5.25 & 2.400 & 1.817 & 1.653 \\
\hline $2 \mathrm{e}$ & $\mathrm{Al}_{2} \mathrm{CoH}_{2}$ & $\mathrm{t}(\mathrm{Al}, \mathrm{Al})$ & 2.66 & 8.55 & 5.03 & 2.509 & 1.591 & \\
\hline $3 \mathrm{~b}$ & $\mathrm{Al}_{3} \mathrm{CoH}$ & $\mathrm{t}(\mathrm{Al})$ & 2.05 & 8.28 & 3.40 & 2.528 & 1.618 & \\
\hline $3 c$ & $\mathrm{Al}_{3} \mathrm{CoH}$ & $\mathrm{t}(\mathrm{Al})$ & 2.20 & 7.88 & 2.99 & 2.574 & 1.835 & \\
\hline $3 d$ & $\mathrm{Al}_{3} \mathrm{CoH}_{2}$ & $\begin{array}{ll}\mathrm{n}, & \mathrm{t}(\mathrm{Al}, \\
\mathrm{Al}) & \end{array}$ & 3.06 & 11.25 & 6.37 & 2.565 & 1.618 & \\
\hline $3 e$ & $\mathrm{Al}_{3} \mathrm{CoH}_{2}$ & $\mathrm{t}(\mathrm{Al}, \mathrm{Al})$ & 2.14 & 10.43 & 5.55 & 2.733 & 1.620 & \\
\hline $3 f$ & $\mathrm{Al}_{3} \mathrm{CoH}_{2}$ & $\begin{array}{l}\mathrm{b}, \\
\mathrm{b}(\mathrm{Al}, \mathrm{Co})\end{array}$ & 1.77 & 10.31 & 5.43 & 2.531 & 1.837 & 1.740 \\
\hline $4 \mathrm{~b}$ & $\mathrm{Al}_{4} \mathrm{CoH}$ & $\mathrm{t}(\mathrm{Co})$ & 1.91 & 9.49 & 2.24 & 2.256 & & 1.505 \\
\hline $4 \mathrm{c}$ & $\mathrm{Al}_{4} \mathrm{CoH}_{2}$ & $0, \mathrm{t}(\mathrm{Al}, \mathrm{Al})$ & 1.61 & 12.63 & 5.39 & 2.514 & 1.610 & \\
\hline $4 d$ & $\mathrm{Al}_{4} \mathrm{CoH}_{2}$ & $\begin{array}{l}\text { h, } \\
h(\mathrm{Al}, \mathrm{Co})\end{array}$ & 1.83 & 12.48 & 5.23 & 2.529 & 2.052 & 1.692 \\
\hline $5 b$ & $\mathrm{Al}_{5} \mathrm{CoH}$ & $\mathrm{t}(\mathrm{Al})$ & 1.41 & 11.68 & 2.98 & 2.252 & 1.618 & \\
\hline $5 c$ & $\mathrm{Al}_{5} \mathrm{CoH}$ & $\mathrm{b}(\mathrm{Al}, \mathrm{Co})$ & 1.27 & 11.32 & 2.62 & 2.501 & 1.874 & 1.674 \\
\hline $5 d$ & $\mathrm{Al}_{5} \mathrm{CoH}_{2}$ & $\mathrm{n}, \mathrm{t}(\mathrm{Al}, \mathrm{Al})$ & 1.30 & 14.70 & 6.00 & 2.241 & 1.616 & \\
\hline $5 e$ & $\mathrm{Al}_{5} \mathrm{CoH}_{2}$ & $\mathrm{n}, \mathrm{t}(\mathrm{Al}, \mathrm{Co})$ & 1.54 & 14.40 & 5.70 & 2.291 & 1.615 & 1.577 \\
\hline $5 f$ & $\mathrm{Al}_{5} \mathrm{CoH}_{2}$ & $\mathrm{n}, \mathrm{t}(\mathrm{Al}, \mathrm{Al})$ & 1.64 & 14.28 & 5.58 & 2.262 & 1.624 & \\
\hline $6 \mathrm{~b}$ & $\mathrm{Al}_{6} \mathrm{CoH}$ & $\mathrm{b}(\mathrm{Al}, \mathrm{Al})$ & 2.17 & 13.75 & 2.71 & 2.512 & 1.810 & \\
\hline $6 c$ & $\mathrm{Al}_{6} \mathrm{CoH}$ & $\mathrm{t}(\mathrm{Al})$ & 2.00 & 13.67 & 2.63 & 2.574 & 1.612 & \\
\hline $6 \mathrm{~d}$ & $\mathrm{Al}_{6} \mathrm{CoH}_{2}$ & $\mathrm{o}, \mathrm{t}(\mathrm{Al}, \mathrm{Al})$ & 2.27 & 16.35 & 5.32 & 2.622 & 1.610 & \\
\hline $6 e$ & $\mathrm{Al}_{6} \mathrm{CoH}_{2}$ & $\mathrm{n}, \mathrm{t}(\mathrm{Al}, \mathrm{Al})$ & 1.43 & 16.26 & 5.22 & 2.529 & 1.611 & \\
\hline $6 f$ & $\mathrm{Al}_{6} \mathrm{CoH}_{2}$ & $\mathrm{n}, \mathrm{t}(\mathrm{Al}, \mathrm{Al})$ & 1.52 & 16.08 & 5.05 & 2.620 & 1.609 & \\
\hline $7 \mathrm{~b}$ & $\mathrm{Al}_{7} \mathrm{CoH}$ & $\mathrm{t}(\mathrm{Al})$ & 2.27 & 15.86 & 2.83 & 2.341 & 1.625 & \\
\hline $7 \mathrm{c}$ & $\mathrm{Al}_{7} \mathrm{CoH}$ & $\mathrm{t}(\mathrm{Al})$ & 2.08 & 15.85 & 2.81 & 2.498 & 1.606 & \\
\hline $7 d$ & $\mathrm{Al}_{7} \mathrm{CoH}$ & $\mathrm{b}(\mathrm{Al}, \mathrm{Al})$ & 2.00 & 15.31 & 2.27 & 2.382 & 1.807 & \\
\hline $7 e$ & $\mathrm{Al}_{7} \mathrm{CoH}_{2}$ & $\begin{array}{ll}\mathrm{n}, & \mathrm{t}(\mathrm{Al}, \\
\mathrm{Al}) & \end{array}$ & 1.93 & 18.54 & 5.50 & 2.838 & 1.609 & \\
\hline $7 f$ & $\mathrm{Al}_{7} \mathrm{CoH}_{2}$ & $\mathrm{o}, \mathrm{t}(\mathrm{Al}, \mathrm{Al})$ & 1.69 & 18.46 & 5.42 & 2.419 & 1.608 & \\
\hline $7 \mathrm{~g}$ & $\mathrm{Al}_{7} \mathrm{CoH}_{2}$ & $0, \mathrm{t}(\mathrm{Al}, \mathrm{Al})$ & 1.52 & 18.23 & 5.19 & 2.304 & 1.606 & \\
\hline $8 b$ & $\mathrm{Al}_{8} \mathrm{CoH}$ & $\mathrm{t}(\mathrm{Al})$ & 1.84 & 17.68 & 2.57 & 2.342 & 1.612 & \\
\hline $8 \mathrm{c}$ & $\mathrm{Al}_{8} \mathrm{CoH}$ & $\mathrm{t}(\mathrm{Al})$ & 1.63 & 17.62 & 2.51 & 2.350 & 1.607 & \\
\hline $8 \mathrm{~d}$ & $\mathrm{Al}_{8} \mathrm{CoH}_{2}$ & $\mathrm{o}, \mathrm{t}(\mathrm{Al}, \mathrm{Al})$ & 1.73 & 20.68 & 5.57 & 2.386 & 1.609 & \\
\hline $8 \mathrm{e}$ & $\mathrm{Al}_{8} \mathrm{CoH}_{2}$ & $\begin{array}{ll}\mathrm{n}, & \mathrm{t}(\mathrm{Al}, \\
\mathrm{Al}) & \end{array}$ & 1.59 & 20.34 & 5.23 & 2.398 & 1.608 & \\
\hline $8 f$ & $\mathrm{Al}_{8} \mathrm{CoH}_{2}$ & $\mathrm{o}, \mathrm{t}(\mathrm{Al}, \mathrm{Al})$ & 1.19 & 20.21 & 5.10 & 2.492 & 1.604 & \\
\hline $9 b$ & $\mathrm{Al}_{9} \mathrm{CoH}$ & $\mathrm{t}(\mathrm{Al})$ & 1.37 & 19.51 & 2.64 & 2.378 & 1.605 & \\
\hline $9 \mathrm{c}$ & $\mathrm{Al}_{9} \mathrm{CoH}_{2}$ & $\begin{array}{ll}\mathrm{n}, & \mathrm{t}(\mathrm{Al}, \\
\mathrm{Al}) & \\
\end{array}$ & 1.87 & 22.38 & 5.51 & 2.378 & 1.606 & \\
\hline $9 d$ & $\mathrm{Al}_{9} \mathrm{CoH}_{2}$ & $0, \mathrm{t}(\mathrm{Al}, \mathrm{Al})$ & 1.77 & 22.32 & 5.45 & 2.348 & 1.612 & \\
\hline $10 \mathrm{~b}$ & $\mathrm{Al}_{10} \mathrm{CoH}$ & $\mathrm{t}(\mathrm{Al})$ & 1.57 & 21.49 & 3.10 & 2.378 & 1.604 & \\
\hline $10 \mathrm{c}$ & $\mathrm{Al}_{10} \mathrm{CoH}_{2}$ & $\mathrm{n}, \mathrm{t}(\mathrm{Al}, \mathrm{Al})$ & 1.69 & 24.53 & 6.14 & 2.534 & 1.601 & \\
\hline $10 \mathrm{~d}$ & $\mathrm{Al}_{10} \mathrm{CoH}_{2}$ & $\mathrm{n}, \mathrm{t}(\mathrm{Al}, \mathrm{Al})$ & 1.27 & 23.62 & 5.23 & 2.425 & 1.604 & \\
\hline $11 b$ & $\mathrm{Al}_{11} \mathrm{CoH}$ & $\mathrm{b}(\mathrm{Al}, \mathrm{Co})$ & 1.51 & 23.21 & 2.35 & 2.621 & 1.983 & 1.589 \\
\hline $11 c$ & $\mathrm{Al}_{11} \mathrm{CoH}_{2}$ & $\begin{array}{ll}\mathrm{n}, & \mathrm{t}(\mathrm{Al}, \\
\mathrm{Al}) & \\
\end{array}$ & 1.70 & 26.33 & 5.47 & 2.368 & 1.604 & \\
\hline
\end{tabular}




\begin{tabular}{|l|l|l|l|l|l|l|l|l|}
\hline $11 \mathrm{~d}$ & $\mathrm{Al}_{11} \mathrm{CoH}_{2}$ & $\mathrm{o}, \mathrm{t}(\mathrm{Al}, \mathrm{Al})$ & 1.66 & 26.21 & 5.35 & 2.410 & 1.599 & \\
\hline $12 \mathrm{~b}$ & $\mathrm{Al}_{12} \mathrm{CoH}$ & $\mathrm{t}(\mathrm{Al})$ & 1.39 & 25.58 & 2.88 & 2.527 & 1.602 & \\
\hline $12 \mathrm{c}$ & $\mathrm{Al}_{12} \mathrm{CoH}_{2}$ & $n, \mathrm{t}(\mathrm{Al}, \mathrm{Al})$ & 1.65 & 29.08 & 6.38 & 2.574 & 1.600 & \\
\hline $12 \mathrm{~d}$ & $\mathrm{Al}_{12} \mathrm{CoH}_{2}$ & $\mathrm{n}, \mathrm{t}(\mathrm{Al}, \mathrm{Al})$ & 1.46 & 28.46 & 5.76 & 2.602 & 1.600 & \\
\hline $13 \mathrm{~b}$ & $\mathrm{Al}_{13} \mathrm{CoH}$ & $\mathrm{t}(\mathrm{Al})$ & 1.91 & 27.59 & 2.12 & 2.591 & 1.611 & \\
\hline $13 \mathrm{c}$ & $\mathrm{Al}_{13} \mathrm{CoH}_{2}$ & $n, \mathrm{t}(\mathrm{Al}, \mathrm{Al})$ & 1.72 & 29.82 & 4.35 & 2.422 & 1.675 & \\
\hline $14 \mathrm{~b}$ & $\mathrm{Al}_{14} \mathrm{CoH}$ & $\mathrm{t}(\mathrm{Al})$ & 2.11 & 30.01 & 2.35 & 2.508 & 1.604 & \\
\hline $14 \mathrm{c}$ & $\mathrm{Al}_{14} \mathrm{CoH}$ & $\mathrm{n}, \mathrm{t}(\mathrm{Al}, \mathrm{Al})$ & 1.88 & 33.60 & 6.12 & 2.556 & 1.602 & \\
\hline $15 \mathrm{~b}$ & $\mathrm{Al}_{15} \mathrm{CoH}_{15}$ & $\mathrm{t}(\mathrm{Al})$ & 1.97 & 32.30 & 2.82 & 2.556 & 1.600 & \\
\hline $15 \mathrm{c}$ & $\mathrm{Al}_{15} \mathrm{CoH}_{2}$ & $\mathrm{o}, \mathrm{t}(\mathrm{Al}, \mathrm{Al})$ & 1.90 & 35.16 & 5.68 & 2.405 & 1.602 & \\
\hline
\end{tabular}

The ground-state $\mathrm{Al}_{3} \mathrm{Co}$ cluster is a spin triplet tetrahedron [Fig. 1(3a)] with $\mathrm{C}_{3 \mathrm{v}}$ symmetry and a binding energy of $4.88 \mathrm{eV}$. Two optimized geometries are found for $\mathrm{Al}_{3} \mathrm{CoH}$ cluster, both of the same multiplicity, doublets. Interaction of $\mathrm{H} 1$-fold on top of $\mathrm{Al}_{3} \mathrm{Co}$ [Fig. $1(3 b)]$ with $C_{1}$ symmetry is favorable as compared to a 2-fold edge site of Al [Fig. 1(3c)] with $\mathrm{C}_{\mathrm{s}}$ symmetry by $0.40 \mathrm{eV}$. The $\mathrm{BE}$ is big $(3.40 \mathrm{eV})$ that it is difficult to make further interaction with hydrogen atom. In order to confirm this, I carried out calculation on $\mathrm{Al}_{3} \mathrm{CoH}_{2}$. Three configurations for $\mathrm{H}$ are studied: (i) where two $\mathrm{H}$ atoms are on the top sites of two neighboring $\mathrm{Al}$ atoms [Fig. 1(3d)], (ii) where two $\mathrm{H}$ atoms are on the top site of one $\mathrm{Al}$ atom [Fig. 1(3e)], (iii) where one $\mathrm{H}$ atom is bridging with two $\mathrm{Al}$ atoms and another one with Co and $\mathrm{Al}$ atoms [Fig. 1(3f)] making the $C_{s}$ structure as shown in Figs. 1(3d)-1(3f). The energy difference of the first two of these is $0.82 \mathrm{eV}$ (Table 2). Also the $C_{s}$ structure $3 \mathrm{f}$ lies $0.94 \mathrm{eV}$ higher in energy than the $3 \mathrm{~d}$ structure. The $\mathrm{BE}$ for $2 \mathrm{H}$ is $6.36 \mathrm{eV}$ (Table 2) and it shows that the interaction between two hydrogens on $\mathrm{Al}_{3} \mathrm{Co}$ is not attractive. This energy is higher than the dissociation energy of $\mathrm{H}_{2}(4.60 \mathrm{eV})$. Accordingly, hydrogen is likely to be dissociated on $\mathrm{Al}_{3} \mathrm{Co}$. The distance between two hydrogens on $\mathrm{Al}_{3} \mathrm{Co}$ in the lowest-energy state is $5.32 \AA$ as compared to the bond length of $0.75 \AA$ in $\mathrm{H}_{2}$. Therefore, two hydrogens are in a dissociated configuration. The dissociation can happen on a top site of $\mathrm{Al}_{3} \mathrm{Co}$. Since there are several such sites, the probability for such a dissociative process is also high.
The ground-state found for $\mathrm{Al}_{4} \mathrm{Co}$ is a spin doublet pyramid $\left(\mathrm{C}_{4 \mathrm{v}}\right)$ structure [Fig. 1(4a)] with a binding energy of $7.24 \mathrm{eV}$. The spin multiplicity found for $\mathrm{Al}_{4} \mathrm{CoH}$ is a spin singlet and its structure, different with small clusters above, prefers a top site of Co atom [Fig. $1(4 \mathrm{~b})]$ on it. In the case of two $\mathrm{H}$ on $\mathrm{Al}_{4} \mathrm{Co}$, two $\mathrm{H}$ atoms on the top site of $\mathrm{Al}$ atom [Fig. $1(4 c)]$ is the ground state, and the spin multiplicity is quartet. The structure with two $\mathrm{H}$ atom taking 3-fold hollow site on two $\mathrm{Al}$ and one Co atoms [Fig. 1(4d)] is $0.16 \mathrm{eV}$ higher in energy. Both $4 \mathrm{c}$ and $4 \mathrm{~d}$ geometries are with $\mathrm{C}_{2 \mathrm{v}}$ symmetry.

$\mathrm{Al}_{5} \mathrm{Co}$ is a spin triplet structure [Fig. 1(5a)] with $\mathrm{D}_{3 \mathrm{~h}}$ symmetry. Similar to $\mathrm{Al}_{2} \mathrm{Co}$ and $\mathrm{Al}_{3} \mathrm{Co}$, one $\mathrm{H}$ is most favorable on a top site of $\mathrm{Al}$ atom [Fig. 1(5b)], and it is with a binding energy of $0.36 \mathrm{eV}$ stronger than that of the bridging between $\mathrm{Al}$ and $\mathrm{Co}$ atom adsorption [Fig. 1(5c)]. The BE (2.98 eV) of $\mathrm{H}$ on $\mathrm{Al}_{5} \mathrm{Co}$ is also one of the largest among all the clusters studied. Accordingly, $\mathrm{Al}_{5} \mathrm{CoH}$ should have large abundance. Two $\mathrm{H}$ favor top sites of neighbor $\mathrm{Al}$ and $\mathrm{Al}$ atoms [Fig. 1(5d)]. The BE of this isomer is $6.00 \mathrm{eV}$ which is again quite large and slightly lower than the value for $\mathrm{Al}_{3} \mathrm{CoH}_{2}$. This should also make hydrogen dissociate on this cluster unless there is a barrier. Isomers with two $\mathrm{H}$ on different top sites of $\mathrm{Al}$ and $\mathrm{Co}$ atoms [Fig. 1(5e)] and the same $\mathrm{Al}$ atom have 0.30 and $0.42 \mathrm{eV}$ higher energies, respectively.

For these small clusters the BE per $\mathrm{H}$ is high with $n=1$ and 5 . And the addition of a second $\mathrm{H}$ increases nearly the same value of $\mathrm{BE}$ for $n=2-5$. On the other hand, for $\mathrm{n}=1$, the addition of a second $\mathrm{H}$ increases the $\mathrm{BE}$ 
significantly. My calculations suggest that $\mathrm{H}_{2}$ is likely to be combining at least on AlCo small cluster and these clusters could disintegrate, such as $\mathrm{AlCoH}_{2}$, or combine with others to form energetically more favorable species.

The lowest-energy isomer of $\mathrm{Al}_{6} \mathrm{Co}$ is a capped triangular prism structure [Fig. 1(6a)] with $\mathrm{C}_{2 \mathrm{v}}$ symmetry. Adsorption of single hydrogen on a top, edge or hollow site of $\mathrm{Al}$ atom or Co atom is considered. The BE (2.71 $\mathrm{eV}$ ) of $\mathrm{H}$ on an edge site of two $\mathrm{Al}$ atoms of $\mathrm{Al}_{6}$ Co [Fig. 1(6b)] is the smallest among all the clusters. The fragmentation energy (see below) is also small and this gives further support for the instability of $\mathrm{Al}_{6} \mathrm{CoH}$. Accordingly, it may not have large abundances, and the structure (6c) with hydrogen on a top site lies $0.08 \mathrm{eV}$ high in energy. For two hydrogen atoms on $\mathrm{Al}_{6} \mathrm{Co}$, several configurations are studied. These include two opposite top of $\mathrm{Al}$ and $\mathrm{Al}$ atoms in the different triangle [Fig. 1(6d)], two neighboring top of $\mathrm{Al}$ and $\mathrm{Al}$ atoms in the same triangle [Fig. 1(6e)] and different triangle [Fig. 1(6f)]. The calculated BE's given in Table 2. The most favorable adsorption sites are structure $6 \mathrm{~d}$. The two $\mathrm{H}$ have a similar configuration as in $\mathrm{Al}_{4} \mathrm{CoH}_{2}$. The $\mathrm{BE}$ for $2 \mathrm{H}$ is $5.32 \mathrm{eV}$ and it shows that interaction between two hydrogen on $\mathrm{Al}_{6} \mathrm{Co}$ is not more attractive than clusters discussed above. However, this energy is also higher than the dissociation energy of $\mathrm{H}_{2}\left(\begin{array}{lll}4.6 & 0 & \mathrm{eV}\end{array}\right)$. Accordingly, hydrogen is likely to be dissociated on $\mathrm{Al}_{6} \mathrm{Co}$. The distance between two hydrogens on $\mathrm{Al}_{6} \mathrm{Co}$ in the lowest-energy state is very long as compared to the bond length of $0.75 \AA$ in $\mathrm{H}_{2}$. Therefore, two hydrogens are in a dissociated on $\mathrm{Al}_{6} \mathrm{Co}$. The dissociation can happen on a top site of $\mathrm{Al}_{6} \mathrm{Co}$. Since there are several such sites, the probability for such a dissociative process is also high.

For $\mathrm{Al}_{7} \mathrm{Co}$, the lowest-energy structure is a spin triplet with $C_{s}$ symmetry [Fig. 1(7a)]. One hydrogen adsorption is favorable on the top of the headpiece $\mathrm{Al}$ atom [Fig. 1(7b)]. The $\mathrm{BE}(2.83 \mathrm{eV})$ of $\mathrm{H}$ on $\mathrm{Al}_{7} \mathrm{Co}$ is also one of the smallest among all the clusters studied. Isomers with $\mathrm{H}$ on the top site of capping $\mathrm{Al}$ atom [Fig. 1(7c)] and Co atom [Fig. 1(7d)] are 0.02 and $0.56 \mathrm{eV}$ higher in energies, respectively. The small HOMO-LUMO gap is likely to make further interaction of hydrogen with this cluster energetically not so favorable. In order to confirm this, some calculations are carried out on $\mathrm{Al}_{7} \mathrm{CoH}_{2}$. Several initial configurations are considered for two hydrogens. These include $\mathrm{H}$ atoms on the top of two neighboring $\mathrm{Al}$ and $\mathrm{Al}$ atoms in the lower part of the $\mathrm{Al}_{7} \mathrm{Co}$ cluster [Fig. 1(7e)]. This has the lowest energy. The HOMO-LUMO gap is lower (1.93 eV) and the addition of one more hydrogen to $\mathrm{Al}_{7} \mathrm{Co}$ leads to a gain of 5.50 $\mathrm{eV}$, an increase of more than $2.67 \mathrm{eV}$ in the $\mathrm{BE}$ of $\mathrm{H}$ as compared to one hydrogen on $\mathrm{Al}_{7} \mathrm{Co}$. The other calculated positions for two hydrogens on $\mathrm{Al}_{7} \mathrm{Co}$ are one on top of two distant $\mathrm{Al}$ atoms [Fig. 1(7f)] or two opposite $\mathrm{Al}$ atoms [Fig. 1(7g)]. The energy, the HOMO-LUMO gap, and other structural information are given in Table 2 . The energies of the isomers [Fig. 1(7f, $7 \mathrm{~g})$ ] are close to that of Fig. 1(7e), and their energy differences with $7 \mathrm{e}$ are 0.08 and $0.31 \mathrm{eV}$, respectively.

$\mathrm{Al}_{8} \mathrm{Co}$ has Cs symmetry [Fig. 1(8a)]. This structure can be very roughly decomposed into two interacting entities: structure $\mathrm{Al}_{4} \mathrm{Co}$ and $\mathrm{Al}_{4}$ are bridged with two $\mathrm{Al}-\mathrm{Co}$ and $\mathrm{Al}-\mathrm{Al}$ bonds. Similar to $\mathrm{Al}_{4} \mathrm{Co}$, this cluster would be anticipated not to favor to react with one hydrogen; indeed, the $\mathrm{BE}$ of $\mathrm{H}$ is $2.57 \mathrm{eV}$ similar to $\mathrm{Al}_{4} \mathrm{Co}$ of $2.24 \mathrm{eV}$. One $\mathrm{H}$ is favorable on a top site of $\mathrm{Al}$ atom in the top part of $\mathrm{Al}_{8}$ Co [Fig. 1(8b)], and from now on, all the clusters later have the same geometry. Structure Fig. $1(8 \mathrm{c})$ with $\mathrm{H}$ atom on a top site of another $\mathrm{Al}$ atom is only $0.06 \mathrm{eV}$ less stable. Therefore, the interaction depends very sensitively on the electronic and atomic structures of clusters. Adsorption of two hydrogen are studied on a few selected sites which included two neighboring faces with $\mathrm{H}$ atoms on the different $\mathrm{Al}$ atoms [Fig. 1(8d)], the two $\mathrm{H}$ atoms on the top sites of neighboring $\mathrm{Al}$ and $\mathrm{Al}$ atoms in the upper part of $\mathrm{Al}_{8}$ Co [Fig. 1(8e)], and two opposite top sites of neighboring $\mathrm{Al}$ atoms in the upper part of $\mathrm{Al}_{8} \mathrm{Co}$ [Fig. 1(8f)]. The $8 \mathrm{~d}$ isomer has the lowest energy (Table 2). The $\mathrm{BE}$ of this isomer is $5.57 \mathrm{eV}$, which is larger than $\mathrm{Al}_{\mathrm{n}} \mathrm{Co}(\mathrm{n}=2,4,6$ and 7) and similar to 
AlCo and slightly slower than the value for $\mathrm{Al}_{3} \mathrm{Co}$ and $\mathrm{Al}_{5} \mathrm{Co}$.

The lowest energy structures for $\mathrm{Al}_{9} \mathrm{Co}, \mathrm{Al}_{10} \mathrm{Co}$ and $\mathrm{Al}_{11}$ Co clusters are spin triplet structure with $\mathrm{C}_{1}$ symmetry, spin doublet structure with $\mathrm{C}_{2}$ symmetry, and spin triplet structure with $\mathrm{C}_{1}$ symmetry, respectively. And the binding energies are 16.87, 18.39 and $20.86 \mathrm{eV}$. The $\mathrm{Al}_{9} \mathrm{Co}$ may be viewed as an $\mathrm{Al}$ atom attached to the most stable form of $\mathrm{Al}_{8} \mathrm{Co}$. $\mathrm{H}$ adsorption on $\mathrm{Al}$ atom [Fig. 1(9b)], a doublet, is the most stable with a binding energy of $2.64 \mathrm{eV}$. The ground state corresponding to $\mathrm{Al}_{9} \mathrm{CoH}_{2}$ cluster is a spin singlet with an average Al-As bond length of $2.378 \AA$, which is the same as $\mathrm{Al}_{9} \mathrm{CoH}$. Two $\mathrm{H}$ favor top sites of neighbor $\mathrm{Al}$ and $\mathrm{Al}$ atoms [Fig. 1(9c)]. Just like the $\mathrm{Al}_{3} \mathrm{Co}$ and $\mathrm{Al}_{5} \mathrm{Co}, \mathrm{Al}_{7} \mathrm{Co}$ clusters discussed above. Two $\mathrm{H}$ adsorption on distant $\mathrm{Al}$ and $\mathrm{Al}$ atom [Fig. 1(9d)], a spin singlet is a substable structure with a binding energy of only 0.09 $\mathrm{eV}$ less than the ground state.

Both of $\mathrm{Al}_{10} \mathrm{Co}$ and $\mathrm{Al}_{11} \mathrm{Co}$ clusters adsorb $\mathrm{H}$ on $\mathrm{Al}$ atom [Fig. 1(10b) and 1(11b)], and the lowest energy structures for both $\mathrm{Al}_{10} \mathrm{CoH}_{2}$ and $\mathrm{Al}_{11} \mathrm{CoH}_{2}$ clusters are also two $\mathrm{H}$ prefer on the top sites of neighbor $\mathrm{Al}$ and $\mathrm{Al}$ atoms [Fig. $1(10 \mathrm{c})$ and $(11 \mathrm{c})]$.

For $\mathrm{Al}_{12} \mathrm{Co}$, the $\mathrm{C}_{\mathrm{s}}$ symmetrical $\mathrm{Al}_{12} \mathrm{Co}$ cluster [Fig. 1(12a)] has been computed to be the most stable using B3LYP/lanl2dz method. Adsorption of single hydrogen on the top site of $\mathrm{Al}$ atom [Fig. 1(12b)] is considered. The BE $(2.88 \mathrm{eV})$ of $\mathrm{H}$ on $\mathrm{Al}_{12} \mathrm{Co}$ is one of the largest among all the clusters studied. However, the HOMO-LUMO gap is small $(1.39 \mathrm{eV})$. The small HOMO-LUMO gap is likely to make further interaction of hydrogen with this cluster energetically so favorable. In order to confirm this, calculations on $\mathrm{Al}_{12} \mathrm{CoH}_{2}$ are carried out. Several initial configurations are considered for two hydrogens. These include two $\mathrm{H}$ atoms on the top sites of neighboring and opposite $\mathrm{Al}$ and $\mathrm{Al}(\mathrm{Co})$ atoms in the same hexagon and two $\mathrm{H}$ atoms on the top sites of $\mathrm{Al}$ and $\mathrm{Al} \mathrm{(Co)} \mathrm{atoms} \mathrm{in} \mathrm{the}$ neighboring faces. The $1(12 \mathrm{~d})$ isomer is 0.62 $\mathrm{eV}$ less stable as compared to the 1(12c) isomer that is the most favorable. In order to further check the results obtained from the B3LYP method, BE's for $\mathrm{H}$ on the top sites of $\mathrm{Al}_{12} \mathrm{Co}$ is calculated using the PW91 method. It is found that the BE's of hydrogen is $2.69 \mathrm{eV}$. This result is quite close to the value $(2.88 \mathrm{eV})$ obtained from the B3LYP method.

$\mathrm{Al}_{n} \mathrm{Co}(\mathrm{n}=13-15)$ take the $\mathrm{C}_{1}, \mathrm{C}_{1}$ and $\mathrm{C}_{\mathrm{s}}$ structures as their ground states, respectively. For $\mathrm{Al}_{\mathrm{n}} \mathrm{CoH} \quad(\mathrm{n}=13-15)$, the ground states reveal top $\mathrm{H}$ bonding to the $\mathrm{Al}$ atoms [Fig. $1(13 b), 1(14 b)$ and 1(15b)]. The spin multiplicity found for them are all doublet. Top on the neighboring $\mathrm{Al}$ and Co atoms ground-state structures are found for $\mathrm{Al}_{n} \mathrm{Co}$ $(n=13-15)$ [Fig. 1(13c), 1(14c) and 1(15c)].

\section{Stability and fragmentation behavior}

In order to check the stability of the lowest-energy isomers , vibrational frequencies for selected clusters have been calculated using the B3LYP/lanl2dz level of theory. It is found that the lowest-energy isomers of all kinds of clusters discussed above have all real frequencies and are, therefore, stable. Figure 2 shows the plot of the $\mathrm{BE}$ of one and two $\mathrm{H}$ atoms on $\mathrm{Al}_{n} \mathrm{Co}$ clusters. As discussed in the previous section, the $\mathrm{BE}$ is large for $\mathrm{H}$ with $n=3,5,7,10,12$, and 15 of $\mathrm{Al}_{n} \mathrm{CoH}$ atoms. And, for $2 \mathrm{H}$, clusters with $n=3,5,10,12$, and 14 have higher BE's. The stability of these complexes is further studied from the fragmentation energies (Table 3). Channels with $\mathrm{Al}_{\mathrm{n}-1} \mathrm{CoH}_{\mathrm{m}}, \mathrm{Al}_{\mathrm{n}-2} \mathrm{CoH}_{\mathrm{m}}$, or $\mathrm{Al}_{\mathrm{n}-1} \mathrm{CoH}_{\mathrm{m}-1}$ molecule being one of the fragments have been studied. It is noted that in all these processes, the fragmentation energy is the largest for $\mathrm{Al}_{15} \mathrm{CoH}_{2}$ and therefore, it is expected to be among the most stable species. Also the fragmentation energies for $\mathrm{Al}_{3} \mathrm{CoH}, \mathrm{Al}_{8} \mathrm{CoH}_{2}, \mathrm{Al}_{14} \mathrm{CoH}$, $\mathrm{Al}_{14} \mathrm{CoH}_{2}$, and $\mathrm{Al}_{15} \mathrm{CoH}$ are next largest for all these channels, suggesting them to be other stable clusters. On the other hand the fragmentation energy for $\mathrm{Al}_{13} \mathrm{CoH}_{2}$ is $0.74 \mathrm{eV}$ for $\mathrm{Al}_{\mathrm{n}-1} \mathrm{CoH}_{\mathrm{m}}+\mathrm{Al}$ channel and it is close to the lowest values. The small clusters of $\mathrm{Al}_{4} \mathrm{CoH}$ also have lower values. 
Table 3: Fragmentation energies of $\mathrm{Al}_{n} \mathrm{CoH}_{m}$ clusters with the product $\mathrm{Al}_{n-p} \mathrm{CoH}_{m-q}, \mathrm{p}=1$ and 2, and $q=1$. All the values mean the parent cluster has a larger binding energy than the sum of the BE of the products

\begin{tabular}{|c|c|c|c|c|}
\hline & $\begin{array}{l}\text { Cluster } \\
\left(\mathrm{Al}_{\mathrm{n}} \mathrm{CoH}_{\mathrm{m}}\right)\end{array}$ & $\mathrm{Al}_{\mathrm{n}-1} \mathrm{CoH}_{\mathrm{m}}+\mathrm{Al}$ & $\mathrm{Al}_{\mathrm{n}-2} \mathrm{CoH}_{\mathrm{m}}+\mathrm{Al}_{2}$ & $\mathrm{Al}_{\mathrm{n}-1} \mathrm{CoH}_{\mathrm{m}-1}+\mathrm{AlH}$ \\
\hline $2 b$ & $\mathrm{Al}_{2} \mathrm{CoH}$ & 2.14 & & 1.34 \\
\hline $2 c$ & $\mathrm{Al}_{2} \mathrm{CoH}_{2}$ & 1.52 & & 1.85 \\
\hline $3 b$ & $\mathrm{Al}_{3} \mathrm{CoH}$ & 2.06 & 3.21 & 1.74 \\
\hline $3 d$ & $\mathrm{Al}_{3} \mathrm{CoH}_{2}$ & 2.30 & 2.84 & 2.02 \\
\hline $4 b$ & $\mathrm{Al}_{4} \mathrm{CoH}$ & 1.21 & 2.29 & 1.62 \\
\hline $4 \mathrm{c}$ & $\mathrm{Al}_{4} \mathrm{CoH}_{2}$ & 1.39 & 2.71 & 1.34 \\
\hline $5 b$ & $\mathrm{Al}_{5} \mathrm{CoH}$ & 2.19 & 2.42 & 1.42 \\
\hline $5 d$ & $\mathrm{Al}_{5} \mathrm{CoH}_{2}$ & 2.07 & 2.47 & 2.20 \\
\hline $6 b$ & $\mathrm{Al}_{6} \mathrm{CoH}$ & 2.07 & 3.28 & 2.04 \\
\hline $6 c$ & $\mathrm{Al}_{6} \mathrm{CoH}_{2}$ & 1.57 & 2.64 & 1.56 \\
\hline $7 \mathrm{~b}$ & $\mathrm{Al}_{7} \mathrm{CoH}$ & 2.12 & 3.20 & 1.82 \\
\hline $7 \mathrm{f}$ & $\mathrm{Al}_{7} \mathrm{CoH}_{2}$ & 2.28 & 2.85 & 1.78 \\
\hline $8 b$ & $\mathrm{Al}_{8} \mathrm{CoH}$ & 1.82 & 2.95 & 1.63 \\
\hline $8 d$ & $\mathrm{Al}_{8} \mathrm{CoH}_{2}$ & 2.14 & 3.44 & 1.80 \\
\hline $9 \mathrm{~b}$ & $\mathrm{Al}_{9} \mathrm{CoH}$ & 1.83 & 2.67 & 1.39 \\
\hline $9 \mathrm{~d}$ & $\mathrm{Al}_{9} \mathrm{CoH}_{2}$ & 1.70 & 2.85 & 1.68 \\
\hline $\begin{array}{l}10 \\
b\end{array}$ & $\mathrm{Al}_{10} \mathrm{CoH}$ & 1.97 & 2.82 & 1.60 \\
\hline $\begin{array}{l}10 \\
\mathrm{~d}\end{array}$ & $\mathrm{Al}_{10} \mathrm{CoH}_{2}$ & 2.15 & 2.87 & 2.00 \\
\hline $\begin{array}{l}11 \\
b\end{array}$ & $\mathrm{Al}_{11} \mathrm{CoH}$ & 1.73 & 2.72 & 1.81 \\
\hline $\begin{array}{l}11 \\
d\end{array}$ & $\mathrm{Al}_{11} \mathrm{CoH}_{2}$ & 1.80 & 2.97 & 1.83 \\
\hline $\begin{array}{l}12 \\
b\end{array}$ & $\mathrm{Al}_{12} \mathrm{CoH}$ & 2.37 & 3.12 & 1.71 \\
\hline $12 \mathrm{c}$ & $\mathrm{Al}_{12} \mathrm{CoH}_{2}$ & 2.75 & 3.57 & 2.86 \\
\hline $\begin{array}{l}13 \\
b\end{array}$ & $\mathrm{Al}_{13} \mathrm{CoH}$ & 2.00 & 3.39 & 1.87 \\
\hline $13 c$ & $\mathrm{Al}_{13} \mathrm{CoH}_{2}$ & 0.74 & 2.51 & 1.23 \\
\hline $\begin{array}{l}14 \\
b\end{array}$ & $\mathrm{Al}_{14} \mathrm{CoH}$ & 2.42 & 3.44 & 1.53 \\
\hline $14 \mathrm{c}$ & $\mathrm{Al}_{14} \mathrm{CoH}_{2}$ & 3.78 & 3.54 & 3.01 \\
\hline $\begin{array}{l}15 \\
b\end{array}$ & $\mathrm{Al}_{15} \mathrm{CoH}$ & 2.29 & 3.73 & 1.62 \\
\hline $15 c$ & $\mathrm{Al}_{15} \mathrm{CoH}_{2}$ & 1.55 & 4.35 & 2.13 \\
\hline
\end{tabular}

\section{Bonding nature}

In order to understand the bonding nature of hydrogen on aluminum cobalt clusters, the bond lengths in both hydrogenated clusters and pure aluminum cobalt clusters are discussed. From Table 1 and 2, one finds that the Al-Co bond lengths increase generally as the size of the cluster increases. The Al-Co, $\mathrm{Al}-\mathrm{H}$ and $\mathrm{Co}-\mathrm{H}$ bond lengths for the top adsorption on $\mathrm{Al}_{n} \mathrm{Co}$ clusters are in the range of $2.256-2.622, \quad 1.599-2.052 \AA$ and 
1.505-1.740 A, respectively. Thus, one can conclude that these bond lengths evolve very slowly with cluster size. In addition, the nearly constant value for $\mathrm{Co}-\mathrm{H}$ and $\mathrm{Al}-\mathrm{H}$ bond lengths on different clusters at specific adsorption sites suggests the similar nature of bonding of $\mathrm{H}$ in different clusters. From Table 2 and Fig. 1, one can also see that hydrogen would like to be onefold with the $\mathrm{Al}_{n}$ Co clusters.

\section{Summary}

The result on hydrogen interaction with aluminum cobalt clusters has been presented. Hydrogen undergoes chemisorptions and interacts strongly with aluminum cobalt clusters. The Al-on top sites are the most stable chemisorptions site for one hydrogen adsorption in most $\mathrm{Al}_{n} \mathrm{Co}$ clusters except for $\mathrm{Al}_{n} \mathrm{Co}(\mathrm{n}=1,4,6$, and 11) cluster. Top on the neighboring $\mathrm{Al}$ and $\mathrm{Al}$ atoms ground-state structures of $\mathrm{Al}_{n} \mathrm{Co}(\mathrm{n}=2,3,5,7,9,10,12,13$,
$14,15)$ and top on the opposite $\mathrm{Al}$ and $\mathrm{Al}$ atoms ground-state structures of $\mathrm{Al}_{n} \mathrm{Co}(\mathrm{n}=4$, $6,8,11$ ) are found for two hydrogen adsorption on $\mathrm{Al}_{n} \mathrm{Co}$ cluster. And there is a slight increase in the mean Al-Co bond lengths after $\mathrm{H}$ adsorption on the lowest-energy sites of the most AlCo clusters. In addition, the nearly constant value for $\mathrm{Co}-\mathrm{H}$ and $\mathrm{Al}-\mathrm{H}$ bond lengths on different clusters at specific adsorption sites suggests the similar nature of bonding of $\mathrm{H}$ in different clusters. In general, the binding energy of $\mathrm{H}$ and $2 \mathrm{H}$ are both found to decrease with a decrease in the cluster size. And the result shows that large binding energies of the hydrogen atoms and large highest occupied and lowest unoccupied molecular-orbital gaps for $\mathrm{Al}_{3} \mathrm{CoH}, \mathrm{Al}_{15} \mathrm{CoH}$ and $\mathrm{Al}_{14} \mathrm{CoH}_{2}$ make these species behaving like magic clusters. The stability of these complexes is further suggesting being the stable clusters from the fragmentation energies.

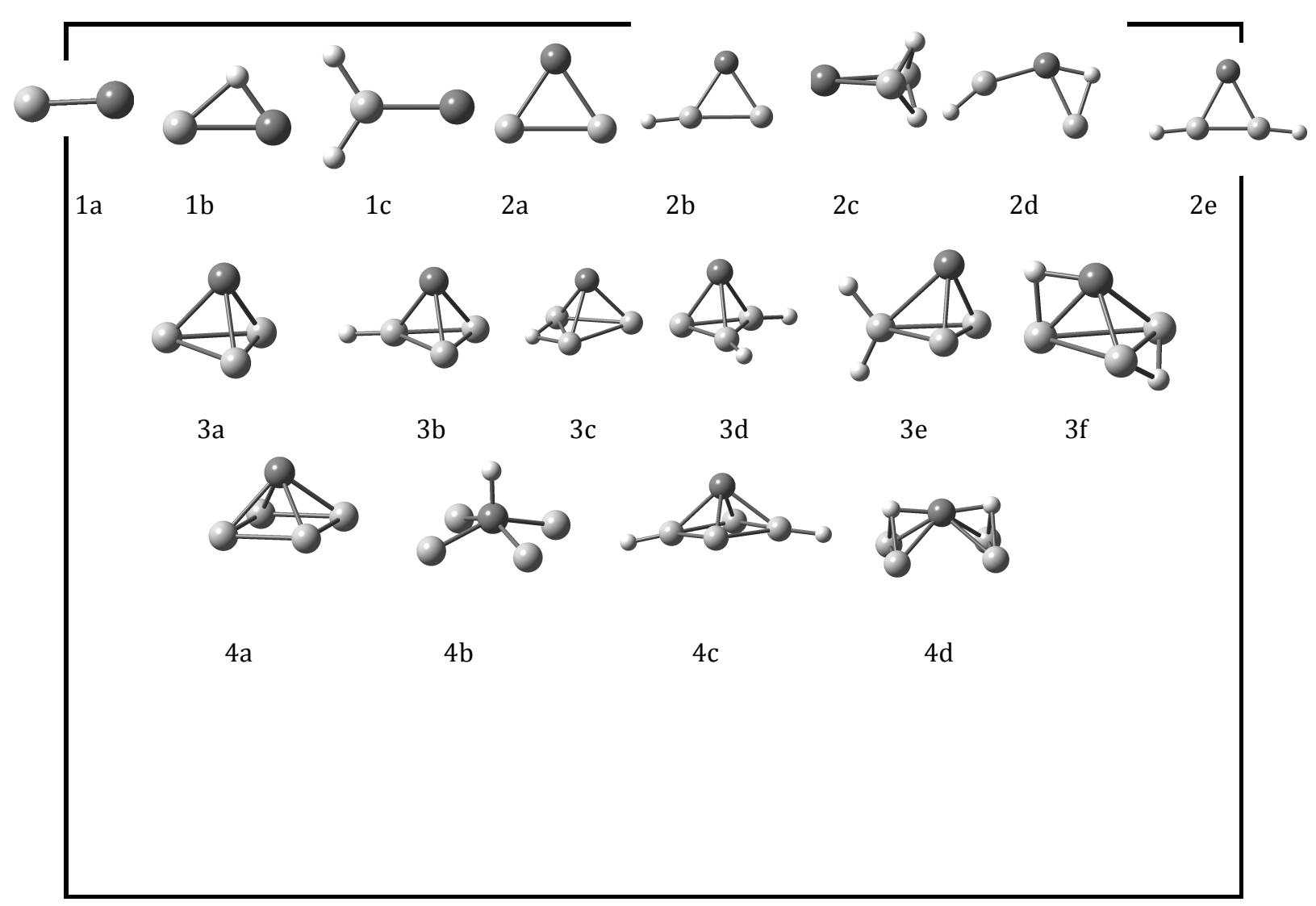

Ling Guo (2014), Journal of Research in Nanotechnology, DOI: 10.5171/2014.850303 


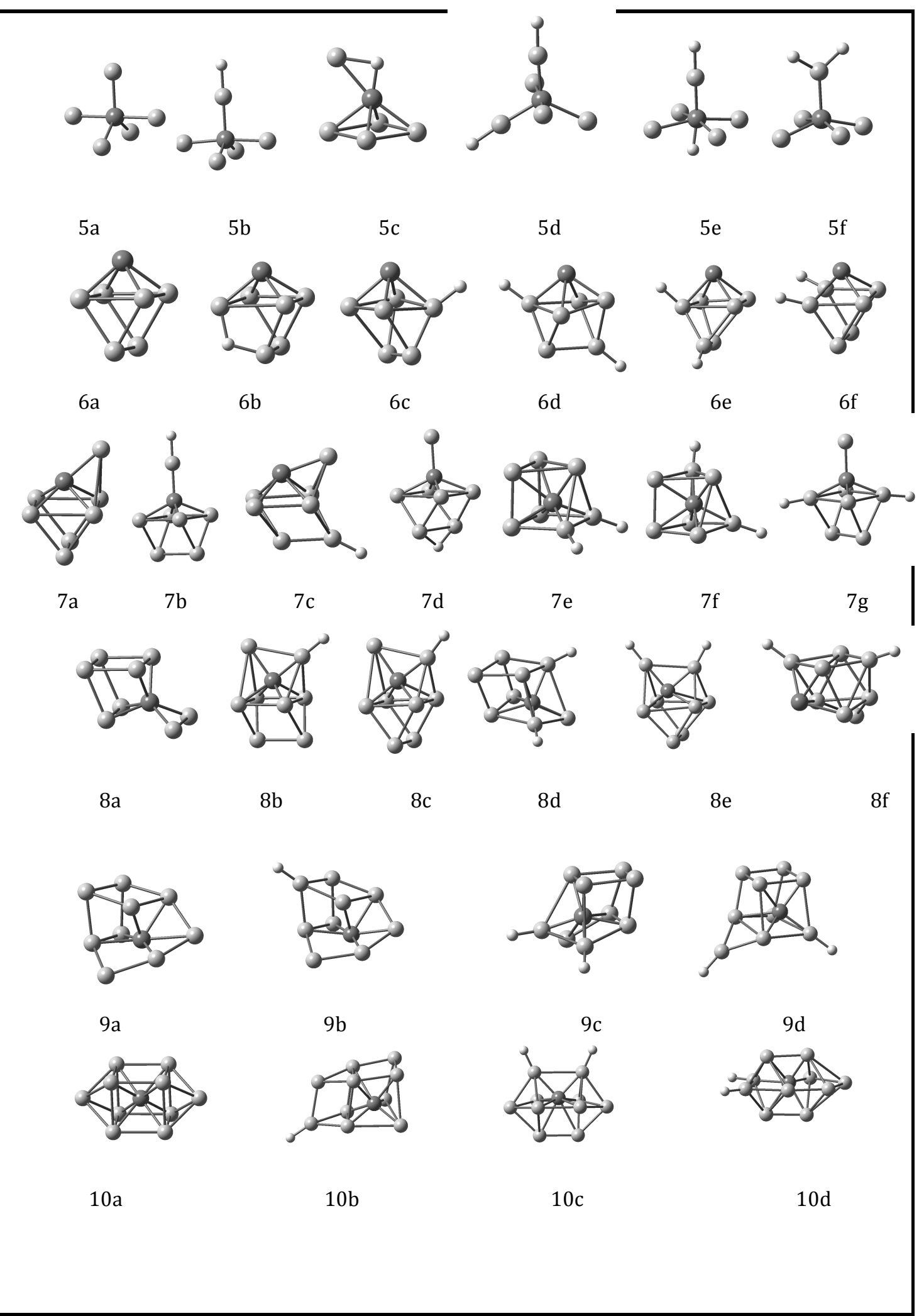

Ling Guo (2014), Journal of Research in Nanotechnology, DOI: 10.5171/2014.850303 

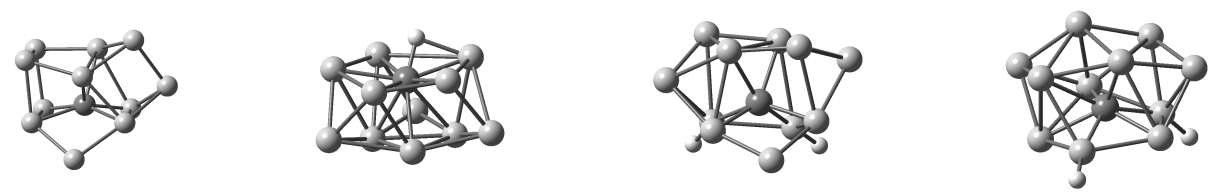

$11 a$

$11 b$

$11 c$

11d
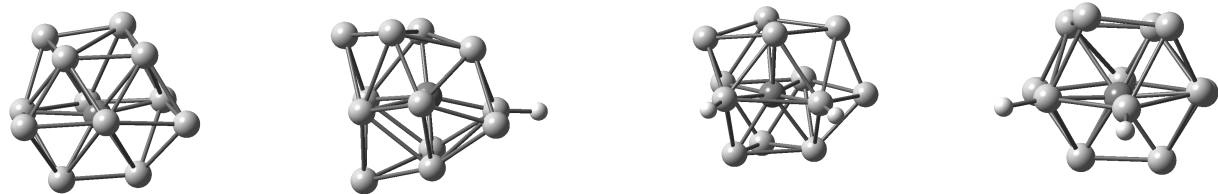

$12 \mathrm{a}$

$12 b$

$12 c$

$12 d$

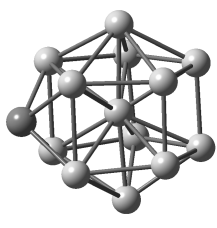

$13 a$

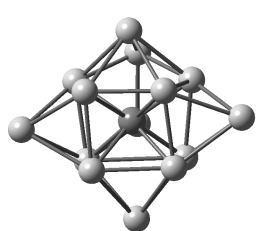

$14 a$

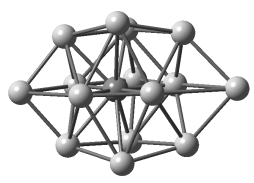

$15 a$

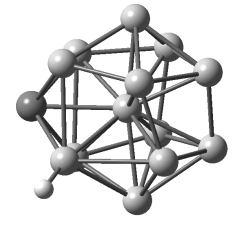

$13 b$
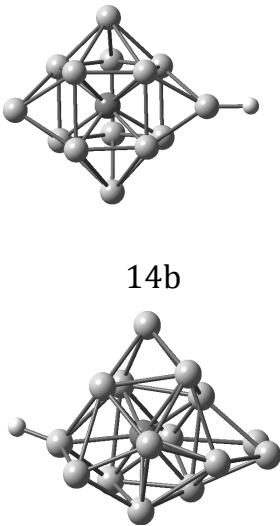

$15 b$

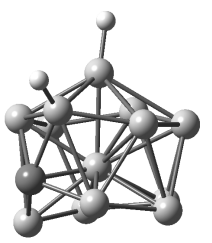

$13 c$
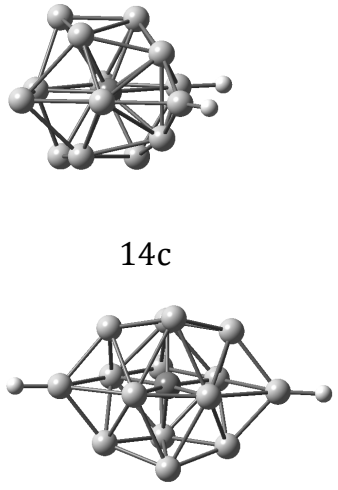

$15 c$

Fig.1 Relaxed structures of $\mathrm{Al}_{n} \mathrm{CoH}_{m}(\mathrm{n}=1-15 ; \mathrm{m}=1,2)$. Gray, black and white balls are used for $\mathrm{Al}$, Co and $\mathrm{H}$, respectively 

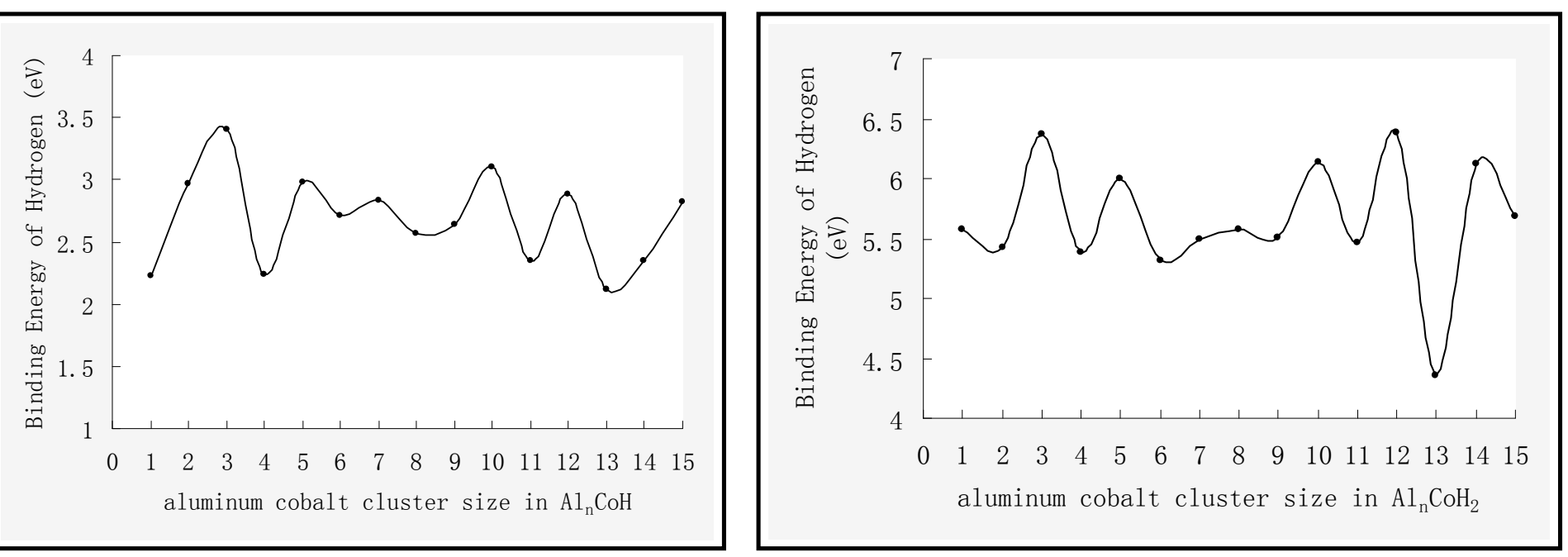

Figure2: Binding energies of $\mathrm{H}$ (left) and $2 \mathrm{H}$ (right) atoms on $\mathrm{Al}_{\mathbf{n}} \mathrm{Co}$ clusters

\section{Acknowledgment}

This work was financially supported by the National Natural Science Foundation of China (Grant No. 20603021), the Natural Science Foundation of Shanxi (Grant No. 2013011009-6), the Youth Academic Leader of Shanxi, Undergraduate Training Programs for Innovation and Entrepreneurship of Shanxi Province (Grant No. 2013145) and Shanxi Normal University (SD2013CXCY-65,105088) and Teaching Reform Project of Shanxi Normal University (SD2013JGXM-51).

\section{References}

1. Andersonsmall, H. H. (1997) Particles and Inorganic Clusters, New York press.

2. Behm, J. M., Brugh, D. J. and Morse, M. D. (1994) "Spectroscopic analysis of the open 3d subshell transition metal aluminides: AlV, AlCr, and AlCo," Journal of Chemical Physics, 101 (8) 6487-6499.

3. Bond, G C. (1987) Heterogeneous catalysis : principles and applications, Clarendon Press, Oxford, New York.

4. Chen, F. Y. and Johnston, R. L. (2008)
"Energetic, Electronic, and Thermal Effects on Structural Properties of Ag-Au Nanoalloys," ACS NANO, 2 (1) 165-171.

5. Guo, L. (2007) "Evolution of the electronic structure and properties of neutral and charged cobalt-doped aluminum clusters," International Journal of Mass Spectrometry, 268 (1) 8-15.

6. Guo, L. (2008) "The cobalt-doped aluminum $\mathrm{Al}_{n} \mathrm{Co}(n=8-16)$ and their anions: Structure, thermochemistry, and electron affinities," Journal of Alloys and Compounds, 466 (1-2) 463-470.

7. Khanna, S. N. and Jena, P. (1994) "Designing ionic solids from metallic clusters," Chemical Physics Letters, 219 (5) 479-483.

8. Knight, W. D., Clemenger, K, de Heer, W. A., Saunders, W. A., Chou, M. Y. and Cohen, M. L. (1984) "Electronic Shell Structure and Abundances of Sodium Clusters," Physical Review Letters, 52 (24) 2141-2143.

9. Koel, B. E. and Somorjai, G. A. (1985) Catalysis, Berlin press.

10. Laguna, A, Lasanta, T, Lopez-de-Luzuriaga, J. M., Monge, M, Naumov, P. and Olmos, M. E. 
(2010) "Combining Aurophilic Interactions and Halogen Bonding To Control the Luminescence from Bimetallic Gold-Silver Clusters," Journal of the American Chemical Society, 132 (2) 456-457.

11. Lahr, D. L. and Ceyer, S. T. (2006) "Catalyzed CO Oxidation at $70 \mathrm{~K}$ on an Extended Au/Ni Surface Alloy," Journal of the American Chemical Society, 128 (6) 1800-1801.

12. Lee, H. M., Ge, M, Sahu, B. R., Tarakeshwar, P. and Kim, K. S. (2003) "Geometrical and Electronic Structures of Gold, Silver, and Gold-Silver Binary Clusters: Origins of Ductility of Gold and Gold-Silver Alloy Formation," Journal of Physical Chemistry B, 107 (37) 9994-10005.

13. Lu, C, Kuang, X. Y., Lu, Z. W., Mao, A. J. and Ma, Y. M. (2011) "Determination of Structures, Stabilities, and Electronic Properties for Bimetallic Cesium-Doped Gold Clusters: A Density Functional Theory Study," Journal of Physical Chemistry A ,115, 9273-9281.

14. Menezes, W. J. C. and Knickelbein, M. B. (1991) "Bimetallic clusters of cobalt and aluminum: ionization potentials versus reactivity, and the importance of geometric structure," Chemical Physics Letters, 183 (5) 357-362.

15. Menezes, W. J. C., Knickelbein, M. B. (1993) "The evolution of electronic structure in $\mathrm{Al}_{\mathrm{n}} \mathrm{Co}_{\mathrm{m}}$," Zeitschrift für Physik D Atoms, Molecules and Clusters, 26 (1) 322-324.

16. Nonose, S, Sone, Y, Onodera, K, Sudo, S. and Kaya, K. (1989) "Reactivity study of alloy clusters made of aluminum and some transition metals with hydrogen," Chemical Physics Letters, 164 (4) 427-432

17. Ouyang, Y. F., Wang, J. C., Hou, Y. H., Zhong, X. P., Du, Y. and Feng, Y. P. (2008) "First principle study of $\mathrm{AlX},(\mathrm{X}=3 d, 4 d, 5 d$ elements and $\mathrm{Lu}$ ) dimmer," Journal of Chemical Physics, 128 (7) 074305-1-6.

18. Passacantando, M, Ottaviano, L, D'Orazio, F, Lucari, F, Biase, M. D., Impellizzeri, G. and
Priolo, F. (2006) "Growth of ferromagnetic nanoparticles in a diluted magnetic semiconductor obtained by $\mathrm{Mn}^{+}$implantation on Ge single crystals," Physical Review B, 73 (19) 195207 (5).

19. Pramann, A, Nakajima, A. and Kaya, K. (2001) "Photoelectron spectroscopy of bimetallic aluminum cobalt cluster anions: Comparison of electronic structure and hydrogen chemisorption rates," Journal of Chemical Physics, 115 (12) 5404-5410.

20. Singh, A. K., Kumar, V. and Kawazoe, Y. J. (2005) "Thorium Encapsulated Caged Clusters of Germanium: Th@Gen, $n=16,18$, and 20," Journal of Physical Chemistry B, 109 (32) 15187-15189

21. Tian, F. Y., Jing, Q. and Wang, Y. X. (2008) "Structure, stability, and magnetism of $\mathrm{Sc}_{\mathrm{n}} \mathrm{Al}$ (n=1-8,12) clusters: Density-functional theory investigations," Physical Review A, 77 (1) 013202 (8).

22. Zanti, G. and Peeters, D. (2010) "DFT Study of Bimetallic Palladium-Gold Clusters $\mathrm{Pd}_{n} \mathrm{Au}_{m}$ of Low Nuclearities $(n+m \leq 14)$," Journal of Physical Chemistry $A, 114$, 10345-10356.

23. Zhao, Y. R., Kuang, X. Y., Zheng, B. B., Li, Y. F. and Wang, S. J. (2011) "Equilibrium Geometries, Stabilities, and Electronic Properties of the Bimetallic $\mathrm{M}_{2}$-doped $\mathrm{Au}_{\mathrm{n}}(\mathrm{M}$ $=\mathrm{Ag}, \mathrm{Cu} ; \mathrm{n}=1-10$ ) Clusters: Comparison with Pure Gold Clusters," Journal of Physical Chemistry A, 115, 569-576. 